\title{
The Effect of Low Velocity Impact Loading on Self- Compacting Concrete Reinforced with Carbon Fiber Reinforced Polymers
}

\author{
Julnar Muhsin Abd \\ Civil Engineering Department \\ College of Engineering \\ University of Baghdad \\ j.abd1901m@coeng.uobaghdad.edu.iq
}

\author{
Ikram Faraoun Ahmed \\ Civil Engineering Department \\ College of Engineering \\ University of Baghdad \\ Ikram.faroun@coeng.uobaghdad.edu.iq
}

\begin{abstract}
Self-Compacting Concrete (SCC) reduces environmental noise and has more workability. This research presents an investigation of the behavior of SCC under mechanical loading (impact loading). Two types of cement have been used to produce SCC mixtures, Ordinary Portland Cement (OPC) and Portland Limestone Cement (PLC), which reduces the emission of carbon dioxide during the manufacturing process. The mixes were reinforced with Carbon Fiber Reinforced Polymer (CFRP) which is usually used to improve the seismic performance of masonry walls, to replace lost steel reinforcements, or to increase column strength and ductility. Workability tests were carried out for fresh SCC. Prepared concrete slabs of $500 \times 500 \times 50 \mathrm{~mm}$ were tested for low-velocity impact loading at ages of 28, 56, and 90 days after water curing. The results were compared with the ones of non-reinforced SCC mixes and show a significant effect on the impact resistance after the SCC was reinforced with CFRP. The strongest impact resistance was recorded for reinforcing slabs made from OPC SCC, while for the reinforced concrete slabs produced from PLC the results were less, but at a close rate.
\end{abstract}

Keywords-self-compacted concrete;carbon fiber reinforced polymer; impact loading test; Portland limestone cement

\section{INTRODUCTION}

Self-Compacted Concrete (SCC) is a kind of concrete that is cast without being compacted and fills the formwork with its own weight. SCC provides some advantages in comparison with traditional concrete, including enhanced building quality, quicker construction activity, lower costs, increased in-situ concrete quality under challenging casting loads, decreased accidents, noise and vibrations, while it assists in the attainment of higher surface quality [1]. One of the drawbacks of SCC is its large cost, which is due to the usage of large amounts of Portland Cement (PC) and chemical additives. The SCC cost will be lowered if the mineral additions replace a portion of the PC, particularly if the mineral additives are industrial waste or by-products. Furthermore, the use of mineral additives in the manufacturing of SCC has not only economical but also environmental benefits [2]. Cement manufacturing emits a large quantity of carbon dioxide and necessitates a large amount of energy [3]. Blending limestone with conventional OPC or intergrading limestone and cement clinker produces Portland Limestone Cement (PLC). The increased use of PLC in the concrete industry is mostly owed to its lower raw material usage and energy savings in clinker production [4]. Components made of Fiber Reinforced Polymer (FRP) have been utilized extensively and effectively in seismic enhancement projects [5].

Traditional metal and ceramic materials are being displaced in a wide range of high-performance implant applications due to their high specific strength, superior corrosion resistance, low weight, and design flexibility. The fiber-matrix interface is essential to the performance of fiber-reinforced composites. A visible interface can guarantee that stress is effectively transmitted from the weaker matrix to the stronger fiber, reducing stress concentrations and improving the overall mechanical characteristics [6]. Throughout their functioning lives, many structures or structural parts are likely to be subjected to impact forces or even repeated impacts. Impact forces can occur by a variety of causes. One example is the impact of moving automobiles on columns and walls of structures in accidents. Other instances include the effect of dropped items from high elevations, the effects of projectiles in wars or terror acts and the effects of water on hydraulic infrastructure, offshore structures, or bridge piers. Impact forces apply short-term dynamic loads to the material, subjecting it to unusual and unwanted stresses, particularly in brittle materials such as concrete. This type of loading necessitates improved microstructural performance in order to be efficiently absorbed. Additive fibers can improve concrete responsiveness under static and dynamic loads. Several testing techniques have been developed in order to get a satisfactory measurement of FRC impact resistance. The drop-weight, projectile impact Charpy pendulum, and the explosive and Repeated Blows Drop-Weight Impact (RBDWI) tests are among them [7].

\section{MATERIAL CHARACTERIZATION}

\section{A. Cement}

In this study, two types of cement were employed, PLC and OPC. The PLC was manufactured in Karbala city in Iraq by the 
Lafarge Company, it is commercially known as Karasta, and it was purchased at a local market. To minimize exposure, it was stored in a dry area. Tables I and II show the chemical composition and the physical properties of the Karasta cement. This cement complied with the EN 197-1:2011 [8]. OPC commercially known as Mass was also utilized. Its physical and chemical properties conform to the Iraqi Standard No. 5 of 2019 [9] and are given in Tables III and IV.

TABLE I. CHEMICAL COMPOSITION OF KARASTA CEMENT

\begin{tabular}{|c|c|c|}
\hline Compound & Percentage by weight & Limit of EN 197-1:2011 \\
\hline Magnesia $(\mathrm{MgO})$ & 1.83 & $\leq 5 \%$ \\
\hline Sulfate $\left(\mathrm{SO}_{3}\right)$ & 2.35 & $\leq 2.5$ \\
\hline $\mathrm{CaO}$ & 62.11 & $\leq 4$ \\
\hline $\mathrm{L} . \mathrm{O} . \mathrm{I}$ & 7.44 & \\
\hline $\mathrm{SiO}_{2}$ & 18.39 & \\
\hline $\mathrm{Al}_{2} \mathrm{O}_{3}$ & 4.63 & \\
\hline $\mathrm{Fe}_{2} \mathrm{O}_{3}$ & 2.77 & \\
\hline $\mathrm{Total}_{\mathrm{C}} \mathrm{A}$ & 99.52 & \\
\hline $\mathrm{C}_{3} \mathrm{~A}$ & 7.58 & $\leq 0.10 \%$ \\
\hline Chloride content & 0.01 & $\leq 1.5$ \\
\hline $\mathrm{I} . \mathrm{R}$ & 1.38 & \\
\hline
\end{tabular}

TABLE II. PHYSICAL PROPERTIES OF KARASTA CEMENT

\begin{tabular}{|c|c|c|}
\hline Physical properties & Test result & Limits of EN 197-1:2011 \\
\hline $\begin{array}{c}\text { Specific surface area } \\
\text { (Blaine method) } \mathrm{cm}^{2} / \mathrm{g}\end{array}$ & 4875 & $\geq 2500$ \\
\hline Initial setting (min) & 90 & $\geq 45$ \\
\hline \multicolumn{2}{|c|}{ Compressive strength (MPa) at: } \\
\hline 2 days & 8 & $\geq 10-20$ \\
\hline 28 days & 34 & $\geq 42.5$ \\
\hline
\end{tabular}

TABLE III. CHEMICAL COMPOSITION OF MASS CEMENT

\begin{tabular}{|c|c|c|}
\hline Oxides & Test results & $\begin{array}{c}\text { Limits of the Iraqi standard } \\
\text { No.5/2019 for OPC }\end{array}$ \\
\hline $\mathrm{CaO}$ & 62.32 & - \\
\hline $\mathrm{SiO}_{2}$ & 21.34 & - \\
\hline $\mathrm{Al}_{2} \mathrm{O}_{3}$ & 4.93 & - \\
\hline $\mathrm{Fe}_{2} \mathrm{O}_{3}$ & 5.43 & - \\
\hline $\mathrm{MgO}$ & 2.12 & Max 5\% \\
\hline $\mathrm{SO}_{3}$ & 2.35 & Max2.8\% \\
\hline L.O.I. & 1.72 & Max 4\% \\
\hline LSF & 0.86 & $0.66-1.02$ \\
\hline $\begin{array}{l}\text { Saturation } \\
\text { coefficient }\end{array}$ & 0.83 & $\operatorname{Max} 1.5 \%$ \\
\hline \multicolumn{3}{|c|}{ Constituent\% according to Bogue equations } \\
\hline $\mathrm{C}_{3} \mathrm{~S}$ & 76.28 & - \\
\hline $\mathrm{C}_{2} \mathrm{~S}$ & 3.73 & - \\
\hline $\mathrm{C}_{3} \mathrm{~A}$ & 6.72 & - \\
\hline $\mathrm{C} 4 \mathrm{AF}$ & 16.5 & - \\
\hline
\end{tabular}

TABLE IV. PHYSICAL PROPERTIES OF MASS CEMENT

\begin{tabular}{|c|c|c|}
\hline Physical properties & Test results & $\begin{array}{l}\text { Limits of the Iraqi standard } \\
\text { No.5/2019 for OPC }\end{array}$ \\
\hline $\begin{array}{c}\text { Specific surface area } \\
\text { (Blaine method) } \mathrm{m}^{2} / \mathrm{kg}\end{array}$ & 376 & $\min 250$ \\
\hline \multicolumn{3}{|c|}{ Setting time (Vicat's apparatus) } \\
\hline Initial setting (min) & $2: 5$ & $\geq 45$ \\
\hline Final setting $(\mathrm{hr})$ & 4:00 & $\leq 10$ \\
\hline $\begin{array}{c}\text { Soundness using } \\
\text { autoclave method }(\mathrm{mm})\end{array}$ & 0.12 & $\leq 0.8$ \\
\hline \multicolumn{3}{|c|}{ Compressive strength (MPa) at: } \\
\hline 2 days & 26 & $\geq 20$ \\
\hline 28 days & 47 & $\geq 42.5$ \\
\hline
\end{tabular}

\section{B. Fine Aggregates}

As fine aggregates, natural sand from the Al-Ukhaider area was used. Table V shows the physical and chemical properties and Table VI shows the sieve analysis of the sand used, which conforms to the limits of Iraq specification No. 45/1984 Zone 2 [10].

TABLE V. CHEMICAL AND PHYSICAL PROPERTIES OF FINE AGGREGATES

\begin{tabular}{|c|c|c|}
\hline Property & Test result & I.Q.S.45: 1984 limits \\
\hline Specific gravity & 2.6 & - \\
\hline Absorption $(\%)$ & 0.72 & - \\
\hline Density $\left(\mathrm{kg} / \mathrm{m}^{3}\right)$ & 1580 & - \\
\hline Sulphate content $\left(\mathrm{SO}_{3}\right)$ & 0.2 & $0.50 \%(\mathrm{max})$ \\
\hline
\end{tabular}

TABLE VI. SIEVE ANALYSIS

\begin{tabular}{|c|c|c|}
\hline Sieve no. & Passing \% & Limits of Iraqi specification no.45/1984 \\
\hline $10 \mathrm{~mm}$ & 100 & 100 \\
\hline $4.75 \mathrm{~mm}$ & 93.3 & $100-90$ \\
\hline $2.36 \mathrm{~mm}$ & 77.7 & $100-75$ \\
\hline $1.18 \mathrm{~mm}$ & 66.6 & $90-55$ \\
\hline $600 \mu \mathrm{m}$ & 54.4 & $59-35$ \\
\hline $300 \mu \mathrm{m}$ & 26.3 & $30-8$ \\
\hline $150 \mu \mathrm{m}$ & 3.1 & 100 \\
\hline
\end{tabular}

\section{Coarse Aggregates (Gravel)}

The maximum size of the crushed gravel used was $10 \mathrm{~mm}$. The gravel was obtained from the Al-Nabaie area in Iraq. Its physical properties were examined in the laboratory of the Ministry of Construction and Housing, Building Research Department, and it satisfies the Iraqi standard IQS No. 45/1984 as shown in Table VII.

TABLE VII. GRADING OF NATURAL COARSE AGGREGATES

\begin{tabular}{|c|c|c|}
\hline $\begin{array}{c}\text { Sieve size } \\
(\mathbf{m m})\end{array}$ & $\begin{array}{c}\text { Cumulative } \\
\text { passing }(\%)\end{array}$ & $\begin{array}{c}\text { Limits of IS NO.45/1984 } \\
\text { for 14-15m m }\end{array}$ \\
\hline 20 & 100 & 100 \\
\hline 14 & 98 & $100-90$ \\
\hline 10 & 75 & $85-50$ \\
\hline 5 & 4 & $10-0$ \\
\hline $\begin{array}{c}\text { Sulphate cotent } \\
\left(\mathrm{SO}_{3}\right)\end{array}$ & 0.6 & Maximum $1 \%$ \\
\hline
\end{tabular}

\section{Limestone Powder}

Limestone powder was used as an inert mineral filler in order to maintain and improve the segregation resistance, to increase the amount of powder (cement and filler), and to increase the workability and density of concrete. Its chemical composition is shown in Table VIII.

TABLE VIII. CHEMICAL COMPOSITION OF LIMESTONE POWDER

\begin{tabular}{|c|c|}
\hline Oxides & $\%$ \\
\hline CaO & 48.28 \\
\hline MgO & 3.97 \\
\hline L.O.I & 42.48 \\
\hline IR & 2.00 \\
\hline
\end{tabular}

\section{E. High Range Water Reducing Admixture (HRWRA)}

Betonac-1030 is a highly efficient polycarboxylate polymer based superplasticizer that is intended to preserve workability 
and improve slump-flow life and thus it provides concrete of extremely high workability without segregation, achieving high initial compressive strength. It permits the constant production of self-compacting concrete and complies with the criteria of ASTM C494 Type F and DIN EN 934-2 [11]. Typically, 0.6\% to $1.5 \%$ of cement weight is used, although this can be modified to fulfill a broader range of concrete specifications. The technical description of Betonac-1030 is presented in Table IX.

TABLE IX. TECHNICAL DESCRIPTION OF BETONAC-1030

\begin{tabular}{|c|c|}
\hline Calcium chloride & nail \\
\hline Solid contents & $40 \%$ \\
\hline PH & 7.5 at $20^{\circ} \mathrm{C}$ \\
\hline Packaging & Available in 220kg drums or 1 100kg IBCs \\
\hline Storage/shelf life & $\begin{array}{l}\text { At least 1 year if stored in originally sealed packaging } \\
\text { and protected from direct sunbeam, extreme heat, and } \\
\text { frost. }\end{array}$ \\
\hline
\end{tabular}

*Manufacturer properties

\section{F. Water}

In concrete mixes and specimen treatment, tap water from the university campus was employed. The temperature of the mixing water was kept constant at $25.2^{\circ} \mathrm{C}$

\section{G. Carbon Fiber Reinforced Polymer}

The carbon fiber used is a mid-strength unidirectional woven carbon fiber fabric commercially known as SikaWrap$300 \mathrm{C}$, intended for either dry or wet use. It is a fabric that may be used in a variety of strengthening purposes. It is flexible and adaptable to various surface planes and geometries (columns, beams, piles, walls, silos, etc). Also, it has a low density and contributes as little weight as possible. In comparison with conventional strengthening, it is highly cost effective. Table $\mathrm{X}$ indicates the technical properties of the carbon fibers used according to the manufacturer company.

TABLE $X . \quad$ CARBON FIBER PROPERTIES

\begin{tabular}{|c|c|c|}
\hline Laminate nominal thickness & $0.167 \mathrm{~mm}$ & \\
\hline $\begin{array}{c}\text { Laminate nominal cross } \\
\text { section }\end{array}$ & $167 \mathrm{~mm}^{2}$ per $\mathrm{m}$ width & \\
\hline Dry fiber density & $1.82 \mathrm{~g} / \mathrm{cm}^{3}$ & \\
\hline Dry fiber thickness & $\begin{array}{c}0.167 \mathrm{~mm} \text { based on fibre } \\
\text { content }\end{array}$ & \\
\hline Area density & $\begin{array}{c}304 \mathrm{~g} / \mathrm{m}^{2} \pm 10 \mathrm{~g} / \mathrm{m}^{2} \text { (carbon } \\
\text { fibres only) }\end{array}$ & \\
\hline Dry fiber tensile strength & $4000 \mathrm{~N} / \mathrm{mm}^{2}$ & \multirow{3}{*}{ ISO 10618} \\
\hline $\begin{array}{l}\text { Dry fiber modulus of } \\
\text { elasticity in tension }\end{array}$ & $230000 \mathrm{~N} / \mathrm{mm}^{2}$ & \\
\hline $\begin{array}{c}\text { Dry fiber elongation at } \\
\text { break }\end{array}$ & $1.7 \%$ & \\
\hline
\end{tabular}

\section{H. Epoxy Impregnation Resin}

Sikadur-330 is an anisotropic epoxy-based impregnating resin and adhesive in two components. It can be utilized in dry and wet applications. The wet application technique requires a primer resin for bonding. It is produced for manual immersion procedures and is simple to mix and apply with a trowel and an insemination roller. It has excellent adhesion to vertical and overhanging surfaces and excellent adherence to a wide range of substrates. Its mechanical characteristics are exceptional and there is no need for a different primer. Table XI indicates the technical properties of Sikadur-330

TABLE XI. PROPERTIES OF SIKADUR-330

\begin{tabular}{|c|c|}
\hline Composition & Epoxy resin \\
\hline Color component & $\begin{array}{c}\text { A: white paste } \\
\text { B: grey paste }\end{array}$ \\
$\mathrm{A}+\mathrm{B}$ mixed: light grey paste
\end{tabular}

\section{Concrete Mixes}

To achieve the research objectives, two types of mixes were prepared according to ACI-211 [12]. The details of the mixes used throughout this investigation are given in Table XII.

TABLE XII. DETAILS OF THE PREPARED MIXES

\begin{tabular}{|c|c|}
\hline Mix symbol & Description of the mix \\
\hline P1 & Reference mix with OPC \\
\hline R1P & Mix with OPC reinforced with carbon fibers \\
\hline P2 & Mix with Karasta LPC \\
\hline R2P & Mix with Karasta LPC reinforced with carbon fibers \\
\hline
\end{tabular}

TABLE XIII. MAIN DETAILS OF THE USED MIXES

\begin{tabular}{|c|c|c|c|c|c|c|c|c|}
\hline \multirow[b]{2}{*}{ Mix } & \multicolumn{2}{|c|}{ Cement Kg/m3 } & \multirow{2}{*}{$\begin{array}{c}\text { FA } \\
\mathrm{kg} / \mathrm{m}^{3}\end{array}$} & \multirow{2}{*}{$\begin{array}{c}\mathrm{CA} \\
\mathrm{kg} / \mathrm{m}^{3}\end{array}$} & \multirow{2}{*}{$\underset{\mathrm{kg} / \mathrm{m}^{3}}{\text { LD }}$} & \multirow{2}{*}{$\underset{\mathrm{kg} / \mathrm{m}^{3}}{\mathrm{~W}}$} & \multirow{2}{*}{$\underset{\mathrm{kg} / \mathrm{m}^{3}}{\mathrm{SP}}$} & \multirow[b]{2}{*}{$\mathbf{W} / \mathbf{p}$} \\
\hline & OPC & PLC & & & & & & \\
\hline P1 & 400 & & 684 & 760 & 80 & 168 & 6 & 0.42 \\
\hline $\mathbf{P 2}$ & & 400 & 684 & 760 & 80 & 168 & 6 & 0.42 \\
\hline
\end{tabular}

\section{J. Mixing Procedure}

The mixing process was carried out in accordance with the ASTMC-192/02 standard [13] and cohesive concrete mixtures were obtained. The mixing steps are: 1. Fine Saturated Surface Dry (SSD) aggregates were mixed with the one-third of water. 2 . The cement and the mineral additives were added along with another one-third of water, and then the ingredients were mixed for one minute. 3 . The SSD coarse aggregates were added with the last third of the water and one third of the superior plasticizer. The mixture was mixed for a minute and a half, and then it was left for half a minute to rest. 4 . Then, two thirds of the remaining superior plasticizer were added and the mixture was mixed well for a minute and a half. 5. The mixture was discharged for testing and pouring. The total mixing time is about 5 minutes.

\section{RESULTS AND DISCUSSION}

\section{A. Fresh Properties}

1) Slump Flow 
Stagnant flow results are shown in Table XV. All results are within the acceptance criteria of EFNARC, 2005 [14] (Table XIV).

TABLE XIV. ACCEPTANCE CRITERIA [14]

\begin{tabular}{|c|c|c|c|}
\hline \multirow{2}{*}{ Method } & \multirow{2}{*}{ Unit } & \multicolumn{2}{|c|}{ Typical range of values } \\
\cline { 3 - 4 } & & Minimum & Maximum \\
\hline Slump flow by Abrams cone & $\mathrm{mm}$ & 650 & 800 \\
\hline T50 cm slump flow & $\mathrm{sec}$ & 2 & 5 \\
\hline V-funnel & $\mathrm{sec}$ & 6 & 12 \\
\hline $\begin{array}{c}\text { Time increase, V-funnel at } \\
\text { T=5min }\end{array}$ & $\mathrm{sec}$ & 0 & 3 \\
\hline U-box & $\mathrm{h} 1-\mathrm{h} 2(\mathrm{~mm})$ & 0 & 30 \\
\hline L-box & $\mathrm{h} 2 / \mathrm{h} 1$ & 0.8 & 1.0 \\
\hline
\end{tabular}

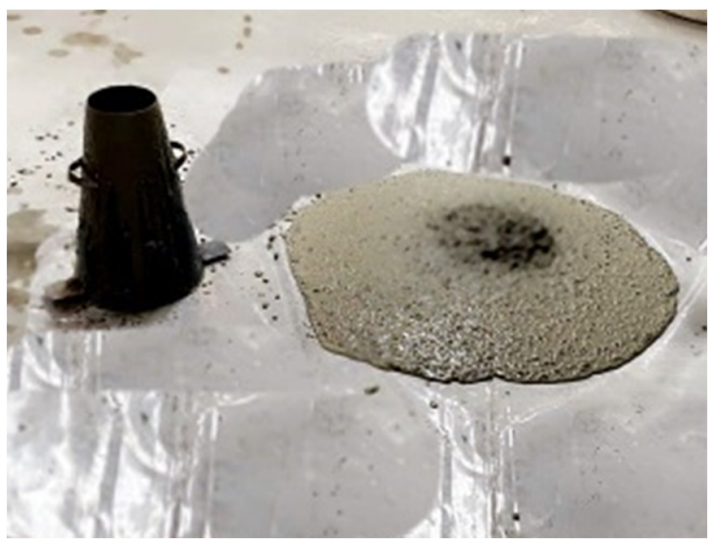

Fig. 1. Slump test.

TABLE XV. SCC RHEOLOGICAL PROPERTIES RESULTS

\begin{tabular}{|c|c|c|c|c|}
\hline Mix & $\begin{array}{c}\text { Slump flow } \\
\text { (mm) }\end{array}$ & $\begin{array}{c}\text { T500 } \\
\text { (sec) }\end{array}$ & $\begin{array}{c}\text { V-funnel time } \\
\text { (sec) }\end{array}$ & $\begin{array}{c}\text { L-box height ratio } \\
\text { (h2/h1) }\end{array}$ \\
\hline OPC & 667 & 5 & 11 & 0.825 \\
\hline PLC & 744 & 3 & 8 & 0.941 \\
\hline
\end{tabular}

\section{2) $7500 \mathrm{~mm}$}

Slump flow times $\left(\mathrm{T}_{500}\right)$ were in the range of $3-5 \mathrm{~s}$. All results are within the acceptance criteria of [14].

\section{3) V-Funnel Time}

The results are consistent with the reported SCC accepted standards [14]. The stagnation values for binary and ternary mixtures that include OPC and PLC are shown in Table XIV. Leveling results range from 667 to $744 \mathrm{~mm}$. Therefore, all mixtures are assumed to have good consistency and workability from the packaging point of view.

\section{4) $L-B o x$}

The L-box height ratios varied from 0.843 to 0.948 (Table $\mathrm{XV}$ ). From the obtained results it was found that the fluidity was good for all the mixtures since it was greater than 0.8 , which is considered the minimum critical value [14].

\section{B. Mechanical Properties (Impact Resistance)}

The device used to measure impact resistance contains three parts:
- The main support part: It consists of an iron bracket that is strong enough to support the examination device during the examination and withstand the impact. It also contains another support for which the examination form is placed. It is made of angle iron and is well fixed to prevent the movement of the form during the examination.

- The iron structure for dropping the block: It is a cylindrical tube with an inner diameter of $10.5 \mathrm{~cm}$ which is fixed with supports that prevent it from moving during the examination. This tube contains openings of different heights $(0.5,1.0,1.7 \mathrm{~m})$. The height of $1 \mathrm{~m}$ was used to examine the reinforced slabs for this research.

- The falling block: It is an iron ball, weighing $3 \mathrm{~kg}$ with a diameter of $9.5 \mathrm{~cm}$. This mass is thrown several times from a height of $1 \mathrm{~m}$ on the model.

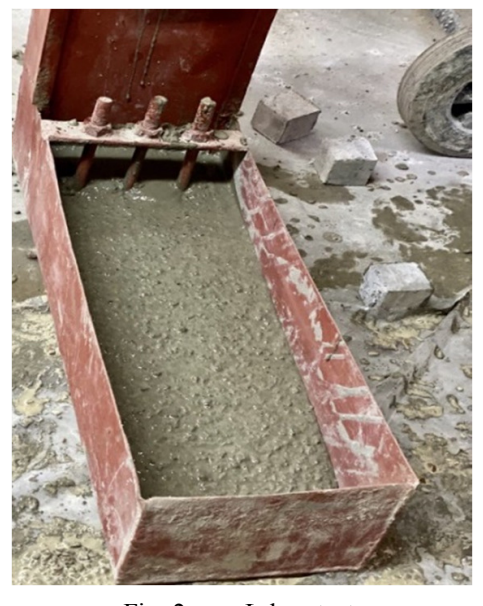

Fig. 2. L-box test.

\section{Examination Method}

Each model was placed on the supporting iron structure, and then the iron block was dropped from the specified height of $1 \mathrm{~m}$ on the model. The number of blows that were required for the first crack to occur and the number of strikes that caused failure are shown in Table XVI. The average of 3 slabs was taken for each variable at ages of 28,56 , and 90 days according to [15]. The failure pattern was observed in the unreinforced slab, which is divided into several pieces. The typical failure behavior of unreinforced concrete specimens under impact resistance is shown in Figure 4. The stages of failure in the reinforced slab were categorized as: in the first stage the first crack occurs, during the second stage fragmentation occurs, and at the third stage failure occurs with cracks in the corners of the slab and the occurrence of a full hole so that the reinforcement appears. The typical failure behavior of reinforced concrete specimens under impact resistance is shown in Figure 5.

Reinforcement of SCC improves the impact resistance because the carbon fiber reinforced with polymer used in this research has good mechanical properties to curb cracking and absorb high energy when withdrawn from the concrete, which makes the reinforced slabs to have high strength and flexibility 
and makes them capable of withstanding external shocks better than SCC without reinforcement. The impact resistance (number of blows) increases with the curing age, as can be seen in Figure 3. This is consistent with the findings in previous studies that examined the reaction of low impact velocity Carbon Fiber Reinforced Polymer (CFRP) epoxy laminates.

TABLE XVI. SLAB UNDER THE IMPACT RESISTANCE TEST

\begin{tabular}{|c|c|c|c|c|c|c|}
\hline & \multicolumn{6}{|c|}{ Average impact resistance } \\
\hline \multirow{3}{*}{ Mix } & \multicolumn{2}{|c|}{28 days } & \multicolumn{2}{|c|}{56 days } & \multicolumn{2}{|c|}{90 days } \\
\hline & \multicolumn{6}{|c|}{ Number of blows required for } \\
\hline & first crack & failure & first crack & failure & first crack & failure \\
\hline P1 & 1 & 2 & 1 & 3 & 1 & 3 \\
\hline P1R & 2 & 40 & 2 & 54 & 2 & 70 \\
\hline $\mathrm{P} 2$ & 1 & 2 & 1 & 2 & 1 & 3 \\
\hline P2R & 2 & 37 & 2 & 49 & 2 & 65 \\
\hline
\end{tabular}

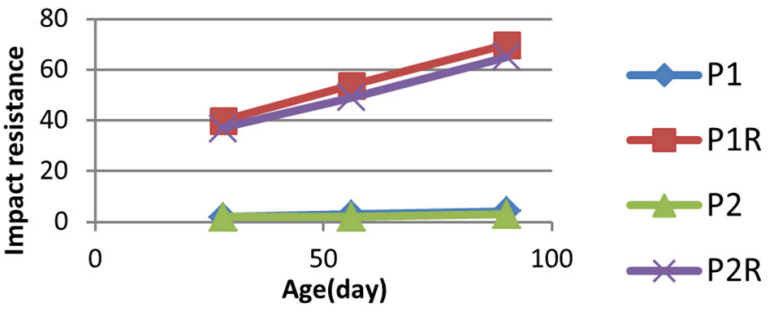

Fig. 3. Impact resistance with different ages of curing.
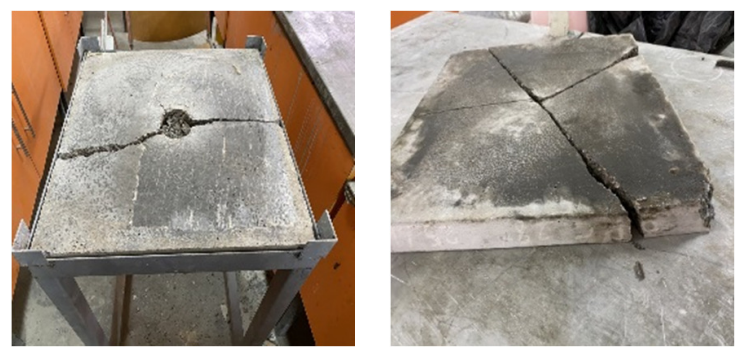

Fig. 4. Typical failure behavior of unreiforced concrete slabs.
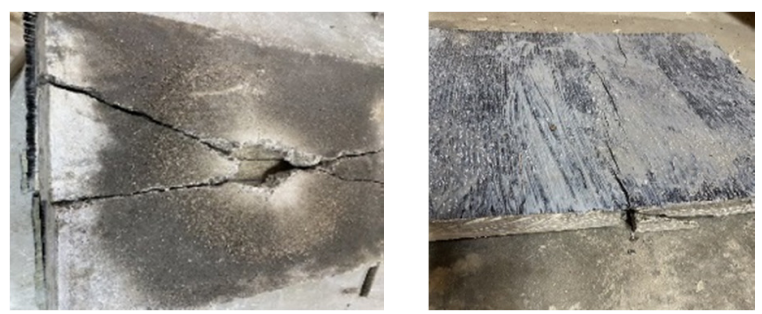

Fig. 5. Typical failure behavior of reiforced concrete slabs.

It is known that damage caused by low impact velocity (where there is no hole) in CFRP laminates rises with the impact energy when submitted to impact loads. As a result, the design of fibers and the sequence of stacking play a crucial part in the compliance under these temperature and loading circumstances with CFRP composites. Thermal variation does not produce interlaminar strains in the plain-woven laminate employed, where the fibers were oriented parallel in each ply, and damage extension after impact does not rise significantly at low temperatures [16]. Based on the extensive experimental data, reinforcing of SCC with the use of recycled CFRP fibers increases the mechanical characteristics and impact resistance of specimens [17].

\section{CONCLUSION}

The following conclusions can be drawn from the results of the experimental work:

- The use of limestone powder as filler for SCC and the replacement percentage do not affect the properties of solid concrete.

- Carbon fibers can be used for reinforcement and consolidation and they show high impact resistance.

- Impact resistance was more powerful and reached 70 blows in slabs containing OPC at the age of 90 days.

- The results between SCC with OPC slabs and SCC with PLC slabs are not so paradoxical.

This research contributes to the understanding of the impact behavior of concrete slabs made with carbon fibers. In practice, concrete slabs reinforced with CFRP and produced from PLC can be used in many different applications. The SCC made with locally available materials could be widely used instead of conventional concrete at complex construction sites. This reinforcing system is used to increase the strength and ductility of columns and the loading capacity of structural elements, enabling changes in use, alterations and refurbishment, and structural design and construction defect corrections. The use of lime dust and PLC to produce sustainable SCC is environmentally beneficial since the carbon dioxide emissions and energy consumption are reduced by reducing the amount of cement being manufactured and used.

\section{REFERENCES}

[1] N. A. Memon, M. A. Memon, N. A. Lakho, F. A. Memon, M. A. Keerio, and A. N. Memon, "A Review on Self Compacting Concrete with Cementitious Materials and Fibers," Engineering, Technology \& Applied Science Research, vol. 8, no. 3, pp. 2969-2974, Jun. 2018, https://doi.org/10.48084/etasr.2006.

[2] M. Uysal and M. Sumer, "Performance of self-compacting concrete containing different mineral admixtures," Construction and Building Materials, vol. 25, no. 11, pp. 4112-4120, Nov. 2011, https://doi.org/ 10.1016/j.conbuildmat.2011.04.032.

[3] N. Bheel, A. S. Memon, I. A. Khaskheli, N. M. Talpur, S. M. Talpur, and M. A. Khanzada, "Effect of Sugarcane Bagasse Ash and Lime Stone Fines on the Mechanical Properties of Concrete," Engineering, Technology \& Applied Science Research, vol. 10, no. 2, pp. 5534-5537, Apr. 2020, https://doi.org/10.48084/etasr.3434.

[4] F. Shaker, A. Rashad, and M. Allam, "Properties of concrete incorporating locally produced Portland limestone cement," Ain Shams Engineering Journal, vol. 9, no. 4, pp. 2301-2309, Dec. 2018, https://doi.org/10.1016/j.asej.2017.04.005.

[5] N. Askarizadeh and M. R. Mohammadizadeh, "Numerical Analysis of Carbon Fiber Reinforced Plastic (CFRP) Shear Walls and Steel Strips under Cyclic Loads Using Finite Element Method," Engineering, Technology \& Applied Science Research, vol. 7, no. 6, pp. 2147-2155, Dec. 2017, https://doi.org/10.48084/etasr.1279.

[6] S. R. Abid, M. L. Abdul-Hussein, N. S. Ayoob, S. H. Ali, and A. L. Kadhum, "Repeated drop-weight impact tests on self-compacting concrete reinforced with micro-steel fiber," Heliyon, vol. 6, no. 1, Jan. Art. no. e03198, 2020, https://doi.org/10.1016/j.heliyon.2020.e03198. 
[7] M. A. Sanjuán and C. Argiz, "The new european standard on common cements specifications EN 197-1:2011," Materiales de Construcción, vol. 62, no. 307, pp. 425-430, Sep. 2012, https://doi.org/10.3989/ mc.2012.07711.

[8] Iraqi Specification No. 5: Portland Cement. Baghdad, Iraq: Central Agency for Standardization And Quality Control, 2019.

[9] Iraqi Specification No. 45: Aggregates. Baghdad, Iraq: Central Agency for Standardization And Quality Control, 1984.

[10] C09 Committee, "Specification for Chemical Admixtures for Concrete," ASTM International, West Conshohocken, PA, USA. https://doi.org/ 10.1520/C0494 C0494M-12.

[11] ACI Committee 211, ACI PRC-211.1-91: Standard Practice for Selecting Proportions for Normal, Heavyweight, and Mass Concrete (Reapproved 2009). ACI, 2002.

[12] "Standard Practice for Making and Curing Concrete Test Specimens in the Laboratory," ASTM International, West Conshohocken, PA, USA, ASTM C192/C192M-07.

[13] BIBM, CEMBUREAU, ERMCO, EFCA, and EFNARC, The European Guidelines for Self-Compacting Concrete: Specification, Production and Use. 2005.

[14] ACI Committee 544, "Design Considerations for Steel Fiber Reinforced Concrete," ACI, West Conshohocken, PA, USA, ACI 544.4R-88, 1988.

[15] T. Gómez-del Río, R. Zaera, E. Barbero, and C. Navarro, "Damage in CFRPs due to low velocity impact at low temperature," Composites Part B: Engineering, vol. 36, no. 1, pp. 41-50, Jan. 2005, https://doi.org/ 10.1016/j.compositesb.2004.04.003.

[16] M. Mastali and A. Dalvand, "The impact resistance and mechanical properties of self-compacting concrete reinforced with recycled CFRP pieces," Composites Part B: Engineering, vol. 92, pp. 360-376, May 2016, https://doi.org/10.1016/j.compositesb.2016.01.046. 